PF 2019 (LXXIV): 59-67

\author{
MARTINA IREINOVÁ \\ Ústav pro jazyk český Akademie věd České republiky, v. v. i. \\ dialektologické oddělení \\ Veveři 97, 60200 Brno \\ tel. +420 532290296 \\ e-mail: ireinova@ujc.cas.cz
}

\title{
NÁŘEČNÍ VÝZKUM V ČECHÁCH, NA MORAVĚ A VE SLEZSKU OD POLOVINY 20. STOLETÍ DO SOUČASNOSTI - METODY, VÝSLEDKY*
}

KLÍČOVÁ SLOVA: dialekty, korespondenční anketa, př́mý terénní výzkum, Český jazykový atlas, Slovník nářečí českého jazyka.

SŁOWA KLUCZOWE: dialekty, ankiety korespondencyjne, badania terenowe, Atlas języka czeskiego, Słownik gwar języka czeskiego.

KEYWORDS: dialects, mail survey, fieldwork, Czech Linguistic Atlas, Dictionary of Czech Dialects.

\author{
RESEARCH OF DIALECT IN BOHEMIA, MORAVIA AND SILESIA \\ FROM MID-20 ${ }^{\mathrm{TH}}$ CENTURY TO THE PRESENT - METHODS, RESULTS
}

\begin{abstract}
Dialects of the Czech national language were examined according to a unified program for the first time after 1879. That year, the paper Navedení pro sberratele (Manual for Collectors) was published; its part Obecná ř č (Common Speech) is considered to be the first questionnaire for research of Czech dialects. The experience and results obtained during this action were also used in further exploration of dialects. Territorially most extensive research was carried out by a correspondence inquiry at the turn of the 40 s and 50 s of the $20^{\text {th }}$ century. It was followed by preliminary works for Český jazykový atlas (the Czech Linguistic Atlas): selection of phenomena for Dotazník pro výzkum českých náreč́ (the Questionnaire for research of Czech dialects), creation of a network of examined localities, direct field research in which Janusz Siatkowski took part as well, in localities with older Czech settlement in the Strzelin region. Since 2011, the mate-
\end{abstract}

* Tento př́spěvek vznikl na základě řešení grantového projektu GA ČR č. 16-04648S Odraz života našich předků $\mathrm{v}$ mizejících slovech. 
rial gained via mail inquiries and the research for the Czech Linguistic Atlas is used for entries of the national Slovník nárečí českého jazyka (the Dictionary of Czech Dialects).

V Česku uskutečňuje systematický výzkum tradičních teritoriálních dialektů českého národního jazyka dialektologické oddělení Ústavu pro jazyk český Akademie věd České republiky, v. v. i. Činnost tohoto oddělení se datuje od roku 1946, kdy Ústav pro jazyk český vznikl. Původně bylo dialektologické oddělení pouze v Praze, v roce 1952 vznikla jeho brněnská pobočka; v roce 1983 byla provedena velká reorganizace Ústavu a veškerá dialektologická práce byla postupně převedena do Brna.

Před vznikem dialektologického oddělení však nářečí v Čechách, na Moravě a ve Slezsku opomíjena nebyla, pozornost jim věnovaly osobnosti našeho vědeckého i kulturního života již takřka o sto let dříve. Jazykovědci zkoumali především nářeční lexikum, s jehož pomocí se snažili obohacovat spisovný jazyk, spisovatelé využívali nářeční prvky ve svých dílech $\mathrm{k}$ dokreslení místa, postav a děje a národopisci zapisovali lidové pohádky, pověsti, bajky a písně. Připomeňme si na tomto místě alespoň krátce počátky dialektologických bádání.

První souhrnný pohled na nářeční rozrůznění přinesla práce Aloisa V. Šembery Základové dialektologie československé (1864). Šembera patřil mezi ty, kdo vyzývali ke sbírání lidových písní, k zapisování lidové slovesnosti ve všech nářečních oblastech pro uchování slovesného bohatství i dalším generacím. Součástí výzev ale nebyly podrobnější pokyny ke sběru materiálu a ke způsobu zapisování nářeční podoby.

V historii dialektologických bádání má své významné místo Navedení ke sbírání pohádek, pověstí, pisni a říkadel, pak obyčejư všeobecných a zejména právních mezi lidem českým. Jedná se o stručný návod pro sběratele folkloru, který vznikl roku 1870 díky tzv. pohádkové komisi literárního a řečnického spolku Slavia, založeného v Praze roku 1869. Podle tohoto Navedení měli sběratelé věnovat pozornost neobvyklým vlastním jménům a jednotlivým slovům neznámým ve spisovném jazyce. Při sběru lidových písní byl kladen důraz jednak na uvedení místa zápisu a jména zpěváka, od něhož sběratel píseň slyšel, jednak na přesný záznam písně po stránce jazykové. Autoři Navedení si již byli vědomi toho, že text zachycený v jeho původní, neupravené podobě má svou odbornou hodnotu a může poskytovat cenný materiál pro poznání českých nářečí.

V roce 1879 bylo publikováno druhé, rozšířené vydání pod názvem Navedení pro sběratele. Podle něj se měli sběratelé zaměřovat na různé okruhy vesnického života, např. ze světa dětí zapisovali ukolébavky, hádanky, rozpočítávání, hry, zaznamenávali písně světské a duchovní, dále pohádky, pověsti, obyčeje a pověry, přísloví a pořekadla, zaměřovali se na pracovní život vesnického lidu, popisovali 
jeho kroj, zabývali se nejen podobou vesnických stavení, ale charakterem celých obcí a jejich uspořádáním. Otázky národopisné byly důležité, ale zároveň se prohluboval i zřetel ke zkoumání místních nářečí. Navedení z roku 1879 obsahovalo část nazvanou Obecná řeč, která je považována za první dotazník pro zkoumání českých nářečí (autoři Navedení užívali termín obecná řeč ve významu 'místní nářečí). Dotazy byly rozděleny do tř́i tematických okruhů, jež se zaměřovaly na názvy jevů jak $\mathrm{v}$ př́ŕrodě, tak $\mathrm{v}$ hospodářství a dále na nářečí. Novátorským počinem bylo to, že se naše nářečí měla poprvé zkoumat na celém českém území podle jednotného programu a měla být sledována komplexně: výzkum se totiž soustředil nejen na hláskosloví, tvarosloví a lexikum (značnou část tematických okruhů lze nalézt i v pozdějších nářečních dotaznících), ale také na větnou melodii, nářeční skladbu, význam slov a vlastní jména (místní, pomístní a osobní).

Navedení měla velký ohlas, uvádí se, že se akce v jejím průběhu účastnilo až 280 sběratelů. $S$ jejich pomocí byl shromážděn jednak bohatý národopisný materiál, jednak údaje o českých nářečích. $\mathrm{V}$ dalších letech se však nepodařilo $\mathrm{v}$ takto rozsáhlém nářečním výzkumu pokračovat. Získaný materiál sice neměl stejnou vědeckou hodnotu, celá akce však přinesla nepopiratelné vědecké výsledky.

Nářeční materiály shromážděné díky spolku Slavie se staly východiskem pro další dialektologické práce jednotlivců a Navedení posloužilo jako vodítko pro další výzkumy v terénu. Členům Slavie se během jejich působení podařilo vytvořit spolehlivou vědeckou základnu pro rozvoj české dialektologie. $Z$ jejich zkušeností čerpali a výsledky jejich činnosti využívali mnozí následovníci. $Z$ některých se stali přední dialektologové, díky nimž se výzkum českých nářečí dále rozvíjel a kteří zajistili dialektologii pevné místo $\mathrm{v}$ rámci jazykovědné bohemistiky.

Jistě by bylo zajímavé zastavit se u velkých osobností české dialektologie, jakými byli Vavřinec J. Dušek, Quido Hodura aj., připomenout si např. lexikografickou činnost Františka Bartoše a Jana F. Hrušky, působení Antonína Frinty, zejména jeho zájem o jazykový zeměpis a zpưsob získávání materiálu pomocí vlastní korespondenční ankety. Opusṫme však přelom 19. a 20. století, přejděme i první polovinu 20. století, v níž např. Bohuslav Havránek představil nový, syntetizující pohled na nářeční diferenciaci národního jazyka ve svém obsáhlém pojednání Nářečí česká (1934).

Soustředme se nyní na rozmach české dialektologie v letech poválečných, kdy záštitu nad systematickým výzkumem našich nářečí převzal Ústav pro jazyk český.

V letech 1947-1953 bylo vypracováno třináct regionálních dotazníků zaměřených především na základní jevy hláskoslovné a morfologické. Cílem bylo prohloubit tehdejší znalosti o našich nářečích, zjistit povahu jednotlivých sledovaných nářečních jevů a získat přehledný obraz o jejich zeměpisném rozšíření; výsledkem měla být komplexní představa o tehdejším stavu dialektů na celém území českého národního jazyka. 


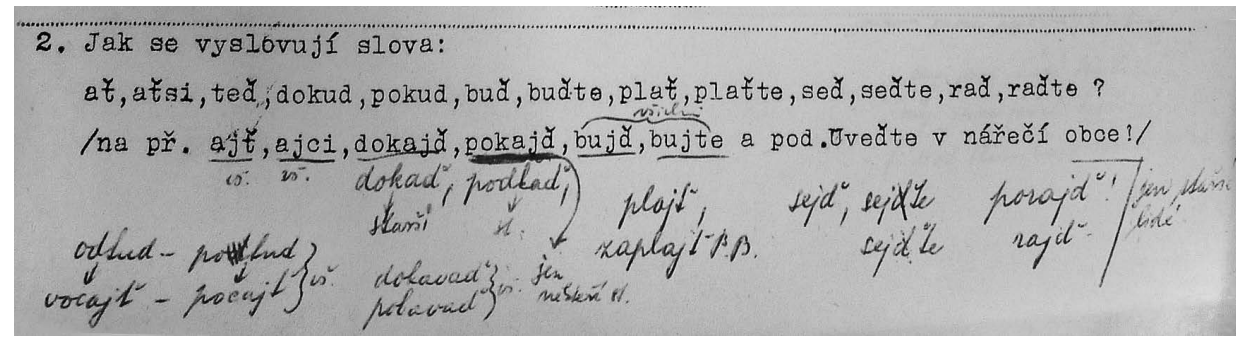

Obrázek 1: Ukázka ze Zvláštního dotazníku pro nářečí západočeská, obec Nevřeň (vyplňovatelé podtrhávali předepsané nářeční podoby užívané v obci a dopisovali další)

Rozsáhlý výzkum se uskutečnil formou korespondenční ankety - dotazníky byly rozeslány téměř do všech obcí, $\mathrm{v}$ nichž se nacházela škola ${ }^{1}$, dotazníky vyplňovali většinou učitelé a zasílali je zpět do Ústavu pro jazyk český (návratnost byla přes $95 \%$ ). Výsledky pak byly výběrově kontrolovány přímým výzkumem $\mathrm{v}$ terénu.

Dotazníky nebyly sice jednotné ani z hlediska rozsahu (od 2 do 44 listů), ani $\mathrm{z}$ hlediska obsahu (zaměřovaly se na zvláštnosti př́slušných nářečních skupin a podskupin, prostřednictvím každého z oblastních dotazníků se zjištoval zeměpisný rozsah důležitých nářečních jevů charakteristických pro danou oblast), ale anketa přesto představuje první systematický, široce založený výzkum tradičních teritoriálních dialektů na celém území českého jazyka.

Kartografování shromážděného materiálu přineslo ucelený pohled na územní rozrůznění našich dialektů. Nejprve vznikaly velkoformátové značkové mapy, zobrazená situace pak byla prrevedena pomocí izoglos na schematické mapky formátu A5. Tyto malé mapky podávající základní přehled o zeměpisném rozšiřrení mapovaných jevů se staly materiálovým východiskem pro zpracovávání kompendia Jaromíra Běliče Nástin české dialektologie (1972). Na základě materiálu shromážděného pomocí oblastních dotazníků vznikly kromě dílčích odborných statí náreční monografie Jaroslava Voráče Česká nářeči jihozápadní (I, 1955; II, 1976) a Slavomíra Utěšeného Nářeči prechodného pásu česko-moravského (1960).

Výzkumy pomocí korespondenční ankety pokračovaly druhou, lexikální fází. Byly sestaveny dva sešity Slovníkového dotazníku pro nárečí českého jazyka (část I, 26 stran, 1954; část II, 20 stran, 1958; viz obrázek 2), na rozdíl od první fáze bylo zadání jednotné pro celé území českého národního jazyka.

Ještě před ukončením korespondenčních anket bylo v polovině padesátých let 20. století rozhodnuto zahájit př́pravné práce na Českém jazykovém atlase (dále ČJA), založeném na anketě př́mé, realizované v terénu dialektology.

1 Sít zkoumaných obcí patří $\mathrm{k}$ nejhustším, jakých bylo v evropských anketách podobného druhu dosaženo. 


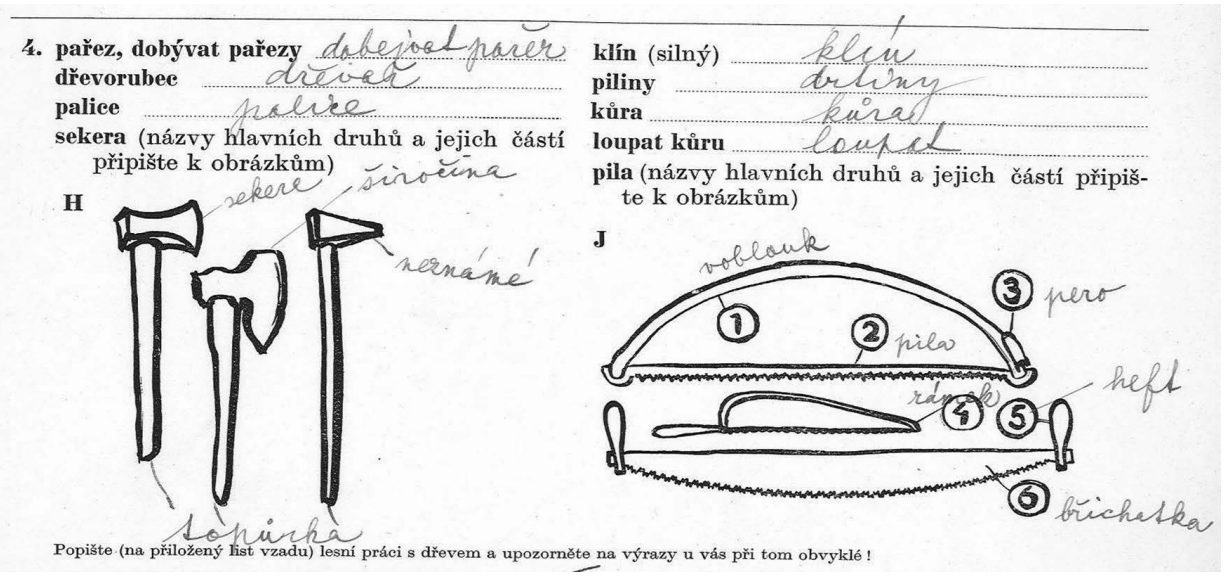

Obrázek 2: Ukázka ze Slovníkového dotazníku pro nářeči českého jazyka (část II), obec Dolní Němčice

Korespondenční ankety přinesly data nezbytná pro přípravu Dotazníku pro výzkum českých nářečí (1964-1965), vybíraly se jevy mající význam pro charakter nářečí a vhodné pro srovnávání a zachycení na mapách. Dotazník, obsahující 2649 otázek, byl rozdělen do dvou oddílů. Oddíl A byl zaměřen zejména na jevy diferencující se lexikálně a slovotvorně a byl uspořádán podle věcněvýznamových souvislostí (viz obrázek 3); v oddíle B byly soustředěny jevy gramatické a syntaktické.

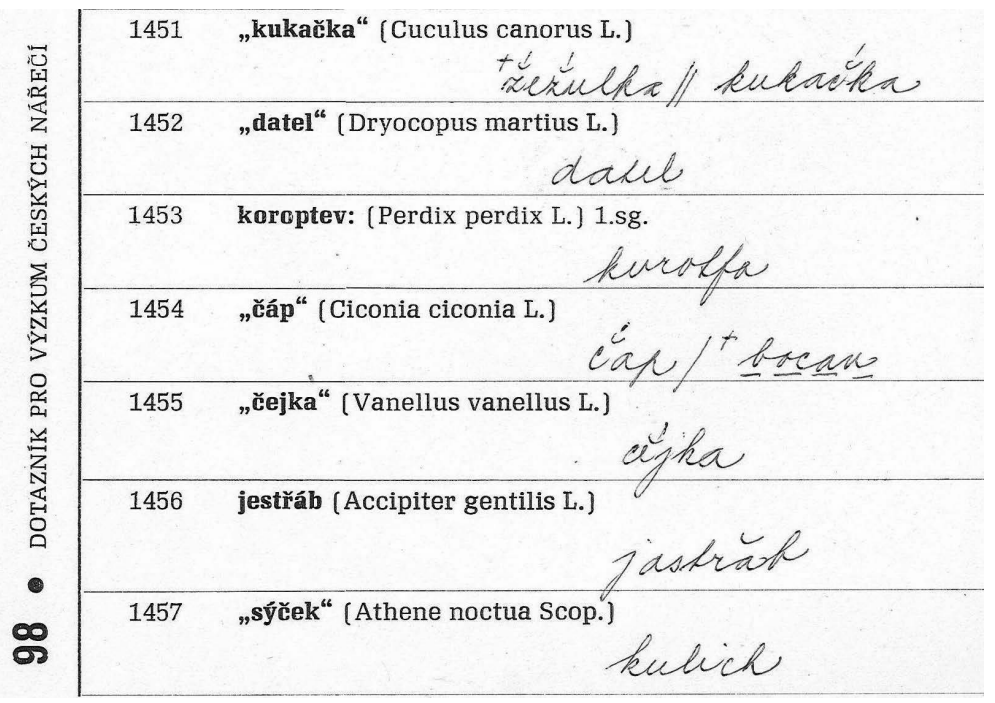

Obrázek 3: Ukázka z Dotazníku pro výzkum českých nářečí, obec Pustějov 
V letech 1964-1972 se podle Dotazníku zkoumalo ve 420 venkovských obcích. Součástí této sítě bylo i pět vesnic ležících $\mathrm{v}$ dnešním Polsku, a to dvě ze starého českého osídlení v Kladsku (Słone a Jakubowice; tzv. Český koutek) a tři z bývalého opavského Slezska (Branice, Pietrowice Wielkie, Krzanowice). Paralelně s tím se nářečí zkoumala též $\mathrm{v}$ dalších třinácti vybraných vesnicích se starší českou kolonizací v zahraničí, a to $\mathrm{v}$ Rumunsku, v bývalé Jugoslávii a v Polsku.

A právě na výzkum v české enklávě na Střelínsku v Polsku vzpomínal takto v knize Rozhovory s českými lingvisty I Pavel Jančák²:

Tehdy už byl v první verzi hotov dotazník pro Atlas, tak ten si vzal doktor Voráč na starost sám a já jsem se staral o magnetofon a o nahrávání. Naším milým a zasvěceným průvodcem byl náš př́tel Janusz Siatkowski, dnes profesor varšavské univerzity a už tehdy čerstvý autor významné monografie o kladské češtině [Siatkowski 1962]. Když si vezmete do ruky cédéčko se zvukovými ukázkami nářečí v Čechách, které jsou vybrány z nahrávek při výzkumu pro Český jazykový atlas a které nám Akademie vydala hlavně díky iniciativě doktorky Bachmannové, tak na tom titulním obrázku je oba vidíte. Je to taková malá mystifikace. Ta „starosvětská” fotografie je totiž právě ze Střelínska. Nám se to zdálo jako velmi případná ilustrace, protože oba stojí před doškovou chalupou s mikrofonem a rozmlouvají u žebřiňáku s „pohádkovým dědečkem”, s panem Zezulkou, a ten má v ruce cep. Ale hlavně, v popředí na židli je náš „dvorní” magnetofon Sonet duo. Je tu tedy věrně představeno pravé prostředí při terénním nahrávání. Tehdy na tom Střelínsku to byla velmi milá spolupráce... (Chromý, Lehečková 2007: 131) (viz obrázek 4, 5).

Ve venkovských lokalitách bylo cílem výzkumu zachycení nejstaršího zjistitelného stavu nářečí, proto byli vybíráni převážně 65-75letí starousedlíci (celkem 4364 osob).

V letech 1973-1976 výzkum pro ČJA pokračoval v 57 městech. Zde šlo o zaznamenání běžné mluvy, proto se ve vnitrozemských městech zkoumalo jak u nejstarší generace (365 osob), tak u 14-15leté mládeže, zatímco v pohraničních městech se sledovala jen mluva nejmladší generace (vzhledem k poválečnému osídlování zde žilo obyvatelstvo nářečně, zčásti i jazykově různorodé; mladých bylo celkem 667). Ve městech výzkum probíhal podle Dotazníku pro výzkum českých nářečí, jen byly vynechány lexikální položky spjaté s reáliemi tradičního života na venkově (např. pojmenování pro pluh, cep a jejich části, pro různé druhy kos, bramborovou nat'). Navíc byl vypracován zvláštní lexikální dotazník obsahující 139 položek zaměřených naopak na reálie spojené s městským životem (nap̌r. pojmenování pro rohový dům, tramvaj; slangové výrazy mládeže pro sestru, žvýkačku aj.).

2 Pavel Jančák se na vzniku ČJA podílel od počátku až po završení celého díla (tj. připravoval Dotazník, účastnil se terénních výzkumů, v prvních dvou svazcích ČJA vedl spolu s Janem Balharem autorský kolektiv, další čtyři svazky recenzoval). 


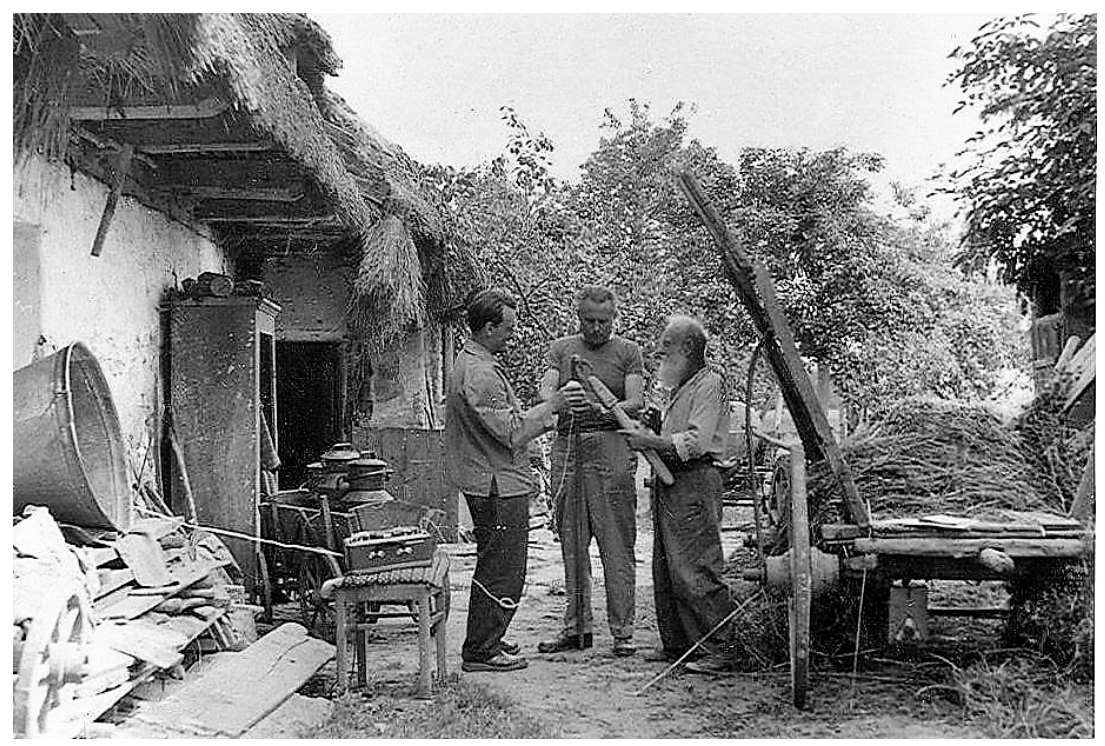

Obrázek 4: Nářeční výzkum pro Český jazykový atlas, obec Kuropatnik (Polsko)

- zleva: Tesla Sonet Duo (na židli); J. Siatkowski, J. Voráč, informátor

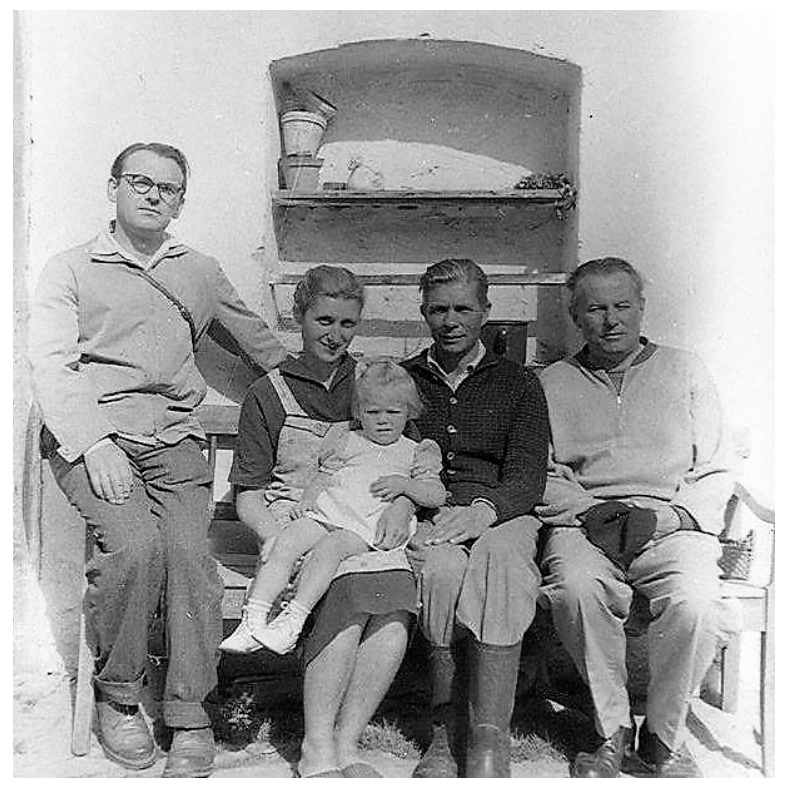

Obrázek 5: Nářeční výzkum pro Český jazykový atlas, obec Horní Poděbrady (Górne Gościęcice, Polsko) - zleva: J. Siatkowski, informátoři, J. Voráč 
Na základě shromážděného materiálu vzniklo šest svazků Českého jazykového atlasu (1992-2011). ČJA 1-5 obsahuje celkem 1558 map a 1578 komentářů. První tři svazky ČJA jsou zaměřeny na lexikální zásobu z významových okruhů „člověk”, „místní a domácí prostředí” (svazek 1), „zahrada a sad”, „živočišstvo”, „les a rostlinstvo”, „krajina”, „čas a počasí”, „vesnice dříve a nyní”, „zábavy a zvyky” (svazek 2), „hospodářská usedlost”, „polní práce, zemědělské nářadí a nástroje”, „dobytek a drůbež" (svazek 3). Čtvrtý svazek představuje územní diference morfologických forem všech ohebných slov. Jádrem pátého svazku je část o vybraných jevech hláskoslovných, zařazeny byly jevy syntaktické a tvoření adverbií, prezentovány jsou i výsledky $\mathrm{z}$ doplňkového výzkumu ve městech a poslední část přináší mapy svazků izoglos excerpovaných z celého ČJA.

Dílo uzavírá svazek Dodatky, jenž obsahuje především kompletní rejstřík nářečních dokladů ze všech pěti svazků, rozsáhlou bibliografii české dialektologie od 1968 r. (starší literatura je uvedena v monografii J. Běliče, 1972), charakteristiky zkoumaných lokalit a dotazníky, na jejichž základě byl celý výzkum realizován. Součástí jsou i dvě $\mathrm{CD}$, obsahující výběr $\mathrm{z}$ audiozáznamů souvislých vyprávění pořízených při nářečním výzkumu pro ČJA. Vedle zvukového záznamu 36 vyprávění z Čech a 34 z Moravy a Slezska jsou publikovány i přepisy těchto ukázek a stručná charakteristika nářečních jevů obsažených v ukázkách. ${ }^{3}$

Od roku 2011 vzniká v dialektologickém oddělení ÚJČ další celonárodní dílo, Slovník nářeči českého jazyka4. Zpracovává lexikální zásobu nářečí v Čechách, na Moravě a ve Slezsku. Materiálovým východiskem je především Archiv lidového jazyka, obsahující nářeční materiál přibližně za posledních 150 let, který je průběžně doplňován nejen excerpty z psaných a tištěných zdrojů, ale i materiálem z př́mých terénních výzkumů. Sleduje se mluva nejstarší generace, při výzkumu se využívá zejména metoda rrízeného rozhovoru, jsou pořizovány zvukové záznamy pro Archiv zvukových záznami̊ náréčnich promluv. Pozornost se věnuje i mluvě nejmladší generace, zejména jejich (ne)znalosti nářečního lexika; $\mathrm{k}$ tomuto účelu jsou sestavovány krátké dotazníky (o zhruba 40 položkách). Terénní výzkumy organizuje dialektologické oddělení pravidelně jednou ročně, vždy v jiné nářeční oblasti. Zavítali jsme např. i na Chodsko, kam podle vzpomínek Pavla Jančáka (Chromý, Lehečková 2007: 130) jezdíval velice rád Jaroslav Voráč „a taky tam rád vodil své vzácné a nejmilejší hosty”. Mezi nimi na prvním místě zmiňuje Janusze Siatkowského.

3 Od roku 2017 je na internetových stránkách ÚJČ (https://cja.ujc.cas.cz/) dostupné 2., elektronické, opravené a doplněné vydání celého ČJA (s výjimkou audiozáznamů, jejich zpř́ístupnění je připravováno).

4 Elektronická verze je zpř́stupňována od roku 2016: https://sncj.ujc.cas.cz/ (nyní jsou dostupná hesla s náslovím A-Č.) 
V dialektologickém oddělení si velice ceníme toho, že se česká nářečí stala předmětem zájmu takového význačného dialektologa, jakým je právě profesor Janusz Siatkowski, a vážíme si jeho spolupráce při výzkumu pro Český jazykový atlas.

\section{Bibliografie}

Bělič Jaromír, 1972, Nástin české dialektologie, Praha.

Český jazykový atlas 1, 1992 (dotisk 2004), Praha.

Český jazykový atlas 2, 1997, Praha.

Český jazykový atlas 3, 1999, Praha.

Český jazykový atlas 4, 2002, Praha.

Český jazykový atlas 5, 2005, Praha.

Český jazykový atlas, Dodatky, 2011, Praha.

Český jazykový atlas [on-line]. <https://cja.ujc.cas.cz/> [cit. 27.10.2018].

Dotazník pro výzkum českých nářečí, 1964-1965, Praha.

Havránek Bohuslav, 1934, Nářečí česká, [in:] Československá vlastivěda III. Jazyk, red. Oldřich Hujer, Praha.

Chromý Jan, Lehečková Eva (red.), 2007, Rozhovory s českými lingvisty I, Praha.

Ireinová Martina, Konečná Hana, 2012, Český jazykový atlas v datech, [in:] Čeština v pohledu synchronním a diachronním (Stoleté kořeny Ústavu pro jazyk český), eds. Světla Čmejrková, Jana Hoffmannová, Jana Klímová, Praha.

Jančák Pavel, 1977, K ukončení výzkumu městské mluvy pro Český jazykový atlas, „Naše řeč", r. 60, Praha.

Jančák Pavel, 1987, Závěrečná etapa prací na Českém jazykovém atlase. „Slovo a slovesnost", r. XLVIII, Praha.

Siatkowski Janusz, 1962, Dialekt czeski okolic Kudowy cz. I, II, Warszawa-Wrocław.

Šembera Alois V., 1864, Základové dialektologie československé, Vídeň.

Slovník náŕečí českého jazyka [on-line]. < https://sncj.ujc.cas.cz/> [cit. 29.10.2018].

Utěšený Slavomír, 1960, Nářečí přechodného pásu česko-moravského, Praha.

Voráč Jaroslav, 1955, Česká nářečí jihozápadní I, Praha.

Voráć Jaroslav, 1976, Česká nářečí jihozápadní II, Praha.

Voráč Jaroslav, 1950, K jazykovému zeměpisu Čech, „Naše řečc, r. 34, Praha.

Voráč Jaroslav, Racková Marie, 1968, Práce na Českém jazykovém atlase, „Slovo a slovesnost", r. XXIX, Praha.

\section{Streszczenie}

W artykule przedstawiono niektóre badania nad gwarami ludowymi przeprowadzone na terenie Czech, Moraw i Śląska. Bogaty materiał gwarowy, znajdujący się w Zakładzie Dialektologii Instytutu Języka Czeskiego Akademii Nauk Republiki Czeskiej, jest od 2011 roku wykorzystywany do opracowania haseł Słownika gwar języka czeskiego. 